\title{
Review of Performance and Emmissions Characteristics of Bio-Additive Fuel on SI Engine Fuelled by Biopetrol
}

\author{
Azizul Mokhtar ${ }^{1,2, a}$, Nazrul Atan ${ }^{1,2}$, Najib Rahman ${ }^{1,2}$, Amir Khalid ${ }^{2, b}$ \\ ${ }^{1}$ Kolej Kemahiran Tinggi Mara Kuantan, KM 8, Jalan Gambang, 25150 Kuantan, Pahang, Malaysia \\ ${ }^{2}$ Combustion Research Group (CRG), Centre for Energy and Industrial Environment Studies \\ (CEIES), UniversitiTun Hussein Onn Malaysia,Parit Raja, BatuPahat, 86400 Johor, Malaysia. \\ aazizul.mokhtar@kktmkuantan.edu.my, bamirk@uthm.edu.my
}

Keywords:bio additive, bio petrol, sparks ignition engine, performance, emissions, biopetrol fuel properties.

\begin{abstract}
Bio-additive is biodegradable and produces less air pollution thus significant for replacing the limited fossil fuels and reducing threats to the environment from exhaust emissions and global warming. Bio-additives can remarkably improve the fuel economy for SI engine and some of the bio-additive has the ability to reduce the total $\mathrm{CO}_{2}$ emission from the internal petrol engine. This review paper focuses to determine a new approach in potential of bio-additives blends operating with bio-petrol on performance and emissions of a spark ignition engine. It is shown that the variant in bio-additives blending ratio and engine operational condition are reduced engine-out emissions and increased efficiency. It seems that the bio-additives can increase the maximum cylinder combustion pressure, improve exhaust emissions and largely reduce the friction coefficient. The review concludes that the additive usage in bio-petrol is inseparable for the better engine performance and emission control and further research is needed to develop bio-petrol specific additives.
\end{abstract}

\section{Introduction.}

Nowadays fuel additive in the marketplace is very synonym for the engine fuel. The main purposes of these additives are to improve the engine performance and decrease the fuel consumption. Most of the additives are fuel-soluble chemicals that can be added into the petrol with the certain volume. Basically, additive can be classified according to their functions such as antiknocks, antioxidants, antirust agent and etc.[1-3]. Now, the researcher and manufacturer are starting looking to produce the additive with environment friendly and the same time very economically of fuel use of goods and services[4].Ethanol, buthanol and methanol are the types of bio-additive that mixture with petrol in high concentration to decrease the fuel consumption and at the same time can increase the engine performance and less pollution [5-6].In Brazil, ethanol is widely used as additive as an anti-knocking agent and able to enhance the engine performance [78]. Ethanol can be produced from sugar cane, corn, wheat and then will undergo the fermentation process.In Malaysia, palm oil was introduced as alternative additive also in purpose to minimize the consumption of fossil fuel rather than just rely on non-biodegradable chemical additive [9].On environmental issue, some additive acting as a rescue by reducing the emission from the engine. The main gases produced from the internal combustion engine that contribute to the overall emission level are carbon monoxide (CO), nitrogen oxide (NOx), hydrocarbons (THC) and many more [10] . Every bio-additive has their own special capability to reduce the emission for the environment. Ethanol-petrol mixture for flex fuel engine has the capability to reduce the NOx emission [11] CO, volatile organic compound (VOC) and unburned hydrocarbon [13].

\section{Effect of Bio-Ethanol in petrol engine}

A brief review of the effect of this ethanol is presented here. Most of the researcher has reported that the performance of blend petrol is higher when an ethanol is used.Koç et al [14]investigated the engine performance of spark ignition engine using ethanol. A single cylinder four stroke spark ignition engine with two compression ratios (10:1 and 11:1) was used in the tests.The author found 
that the ethanol addition to unleaded petrol increase the engine torque and power. Turner et al [15]investigated the combustion performance of bio-ethanol at various blend in single 4 stroke spark-ignition engine. There are two types of injection strategyused and these summarized in Table 1.

Table 1 Test condition [15].

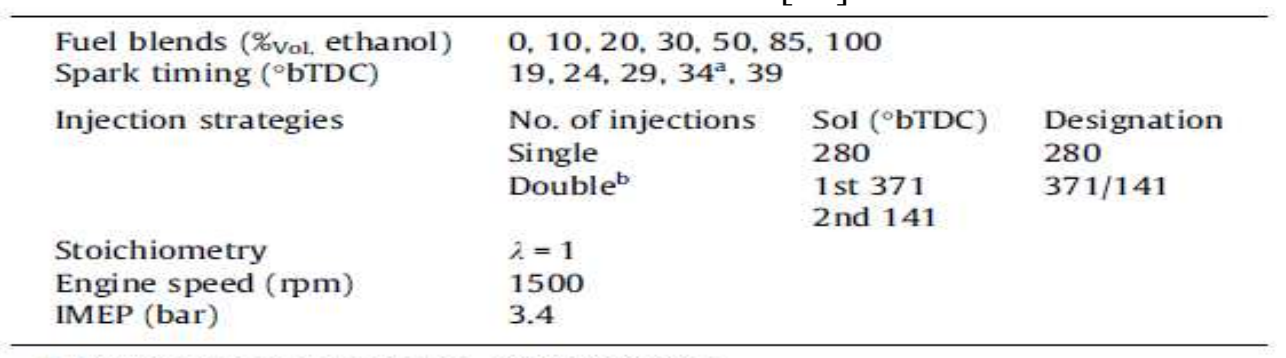

a MBT for standard gasoline, single injection.

b Equal injection duration.

It has been found the $280 \mathrm{Sol}$ case that efficiency is increase as the ethanol content is increased.Al-Hasan[8]performed the test by using $99 \%$ purity of ethanol blended with unleaded petrol to investigate the engine performance and exhaust emission. The best engine performance was found in $20 \%$ of ethanol fuel blend. This result was conducted on four cylinder SI engine (type TOYOTA, TERCEL-3A). The comparison between experimental and theoretical investigation by using petrol-ethanol blends in spark-ignition engines has be made by Bayraktar[16]. From the experimental result, the blend of $7.5 \%$ ethanol was the most suitable for engine performance and from the numerical applications, $16.5 \%$ ethanol was the most suited blend for SI engine.

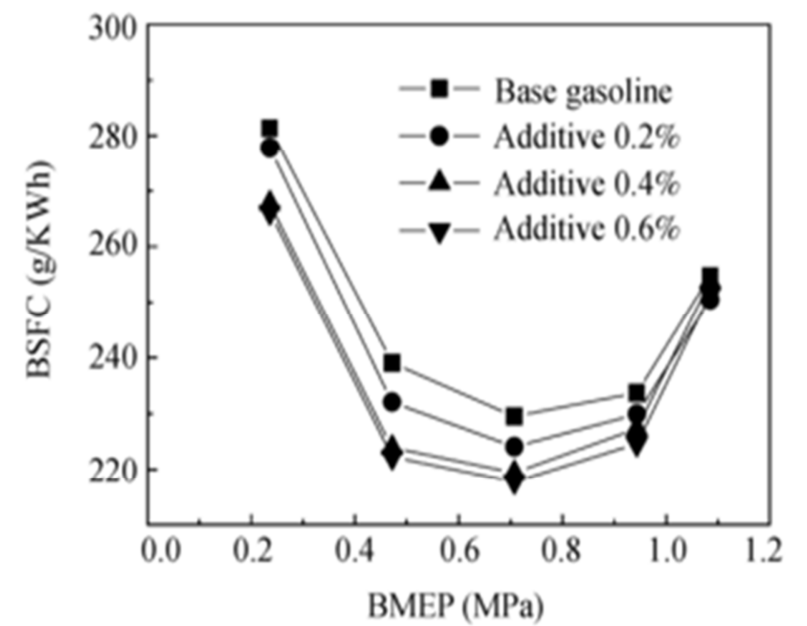

Figure 1: Fuel consumption of prime petrol with additive [17].

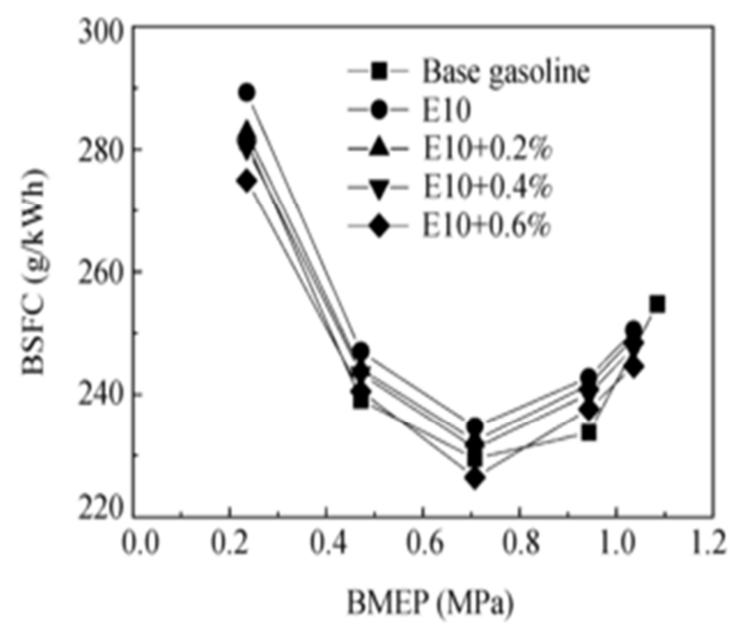

Figure 2: Fuel consumption of E10 petrol with additive [17].

\section{Effect of Bio-Additive in petrol engine}

Yao et al. [17] investigated the effect of bio-additive extracted from the palm oil on fuel economy of the petrol engine. All the investigation has been done by five types of fuels; prime petrol, petrol with known components, petrol blended with $10 \%$ and $20 \%$ of methanol, and $10 \%$ ethanol. Result in Fig. 1 shows the petrol with different ratios of bio-additives have lower fuel consumption in all engine loads and the best blending ratio for the fuel consumption is $0.6 \%$ of additive meanwhile results in Fig. 2 shows the $10 \%$ ethanol with the $0.6 \%$ bio-additive is the best mixture for the brake specific fuel consumption (BSFC). Labeckas and Slavinskas[18]investigated the effect of ethanol and petrol addition on rapeseed oil on the brake mean effective pressure (bmep), brake specific fuel consumption (bsfc), brake thermal efficiency (bte). Test was conducted on four strokes, four cylinder engine, directs injection of diesel engine D-243. Three type of blended fuel were prepared such as rapeseed oil and ethanol (ERO), petrol and rapeseed oil (PRO) and ethanol, petrol and 
rapeseed oil (EPRO) under various blending ratio, speed (RPM) and loads. From the result, ERO of $2.5 \%$ ratio ethanol can improve the efficiency of a fully loaded engine. For the PRO the best ratio to improve efficiency is $2.5 \%$ ratio and for EPRO the best ratio is $5-7.5 \%$ ratio at the full load engine. Srinivasan and Saravanan [19] experimentally investigated the effect of SI engine fuelled with ethanol and oxygenated as a fuel additive. Oxygenated additive was used in volumetric percentage in ethanol-petrol blends with $0.2 \%, 0.3 \%, 0.4 \%$ and $0.5 \%$ of composition. The results showed that, brake thermal efficiency (BTE) is increasing 31.89\% for cycloheptanol oxygenated additives and $32.15 \%$ for cyclooctanol oxygenated additives.

\section{Emission Characteristic}

Many studies regarding the emission effect of ethanol-petrol shows it is can reduce some of the emission gases.Al-Hasan [8], investigated the effect of using unleaded petrol-ethanol (with 99\% purity) blends with different percentage on SI engine performance and exhaust emission.

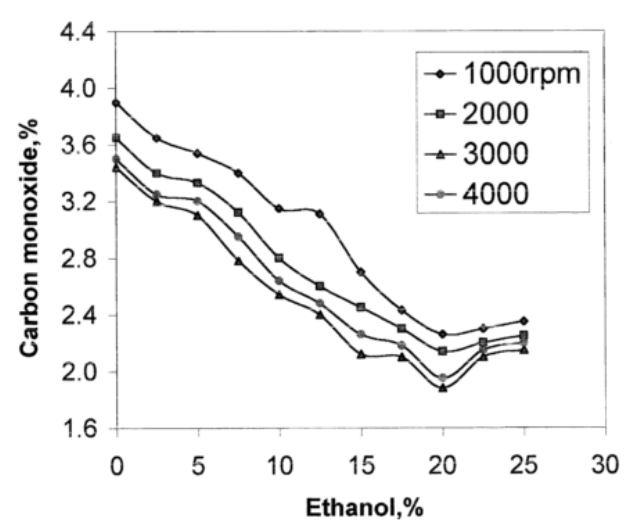

Figure 3 : The effect of ethanol addition on COemission[8]

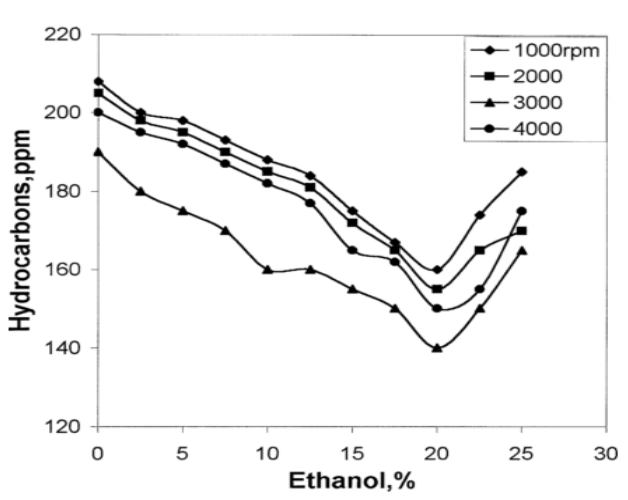

Figure 4 : The effect of ethanol addition on $\mathrm{HC}$ emission[8]

Fig. 3 and 4 shows the effect of emission gases in the fuel blend. The figure showed that the addition of ethanol to unleadedpetrol decreased the $\mathrm{CO}$ and $\mathrm{HC}$ emission concentration. The author concluded these effects occurred due to oxygen content in ethanol fuel.This supported by J.Y. Favez et al. [12] which study the emission of $\mathrm{CO}$ and $\mathrm{HC}$ from the four-stroke motorcycle. The results shows the cold start emission by using petrol-ethanol blended decreased compared to unleaded petrol.Koc et al. [14] using high ethanol concentration $0 \%, 50 \%$ and $85 \%$ mixture with petrol with two different compression ratios of 10:1 and 11:1.
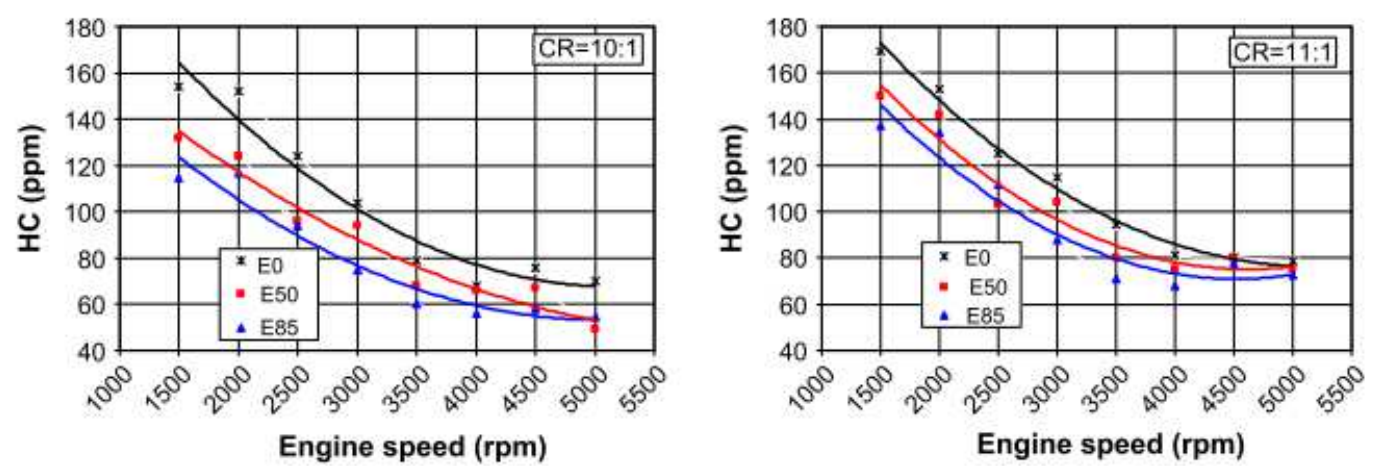

Figure 5 : The effect of unleaded petrol-ethanol blends on $\mathrm{HC}$ emission at different compression ratios [14]

Fig. 5 shows all the emission decrease with the increase of ethanol concentration. All the emission of petrol at CR 11:1 is slightly higher than those of ethanol-petrol blend at a CR of 10:1. Author concludes that the reduction of $\mathrm{HC}$ is due to the presence of oxygen in the ethanol.

Srinivasan and Saravanan [19]studied the effects of ethanol-blended petrol with oxygenated additives on multi-cylinder SI engine. Table 2 and 3 shows the setup of sample volumetric composition. Fig 6 shows that the blend decreased the $\mathrm{CO}$ emission. 
Table 2 : Stage 1 Sample volumetric composition [19]
Table 3 :Stage II Sample volumetric composition [19]

\begin{tabular}{|c|c|c|c|}
\hline $\begin{array}{c}\text { Sample } \\
\text { Name }\end{array}$ & Gasoline & Ethanol & $\begin{array}{c}\text { Oxygenated Additive } \\
\text { [Cycloheptanol] }\end{array}$ \\
\hline Sample 1 & 50.00 & 49.80 & 0.20 \\
\hline Sample 2 & 40.00 & 59.70 & 0.30 \\
\hline Sample 3 & 35.00 & 64.60 & 0.40 \\
\hline Sample 4 & 30.00 & 69.50 & 0.50 \\
\hline Sole Fuel & 100.00 & $\ldots \ldots$ & $\ldots .-$ \\
\hline
\end{tabular}

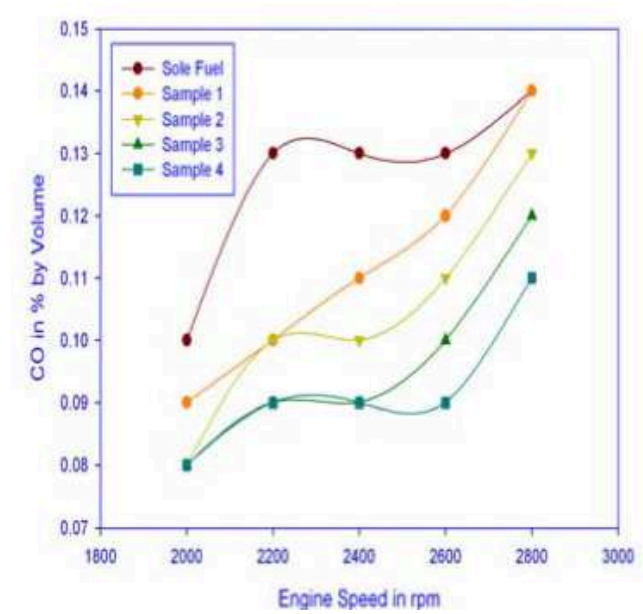

\begin{tabular}{|c|c|c|c|}
\hline $\begin{array}{c}\text { Sample } \\
\text { Name }\end{array}$ & Gasoline & Ethanol & $\begin{array}{c}\text { Oxygenated Additive } \\
\text { [Cyclooctanol] }\end{array}$ \\
\hline Sample 1 & 50.00 & 49.80 & 0.20 \\
\hline Sample 2 & 40.00 & 59.70 & 0.30 \\
\hline Sample 3 & 35.00 & 64.60 & 0.40 \\
\hline Sample 4 & 30.00 & 69.50 & 0.50 \\
\hline Sole Fuel & 100.00 & $-\cdots--$ & $-\cdots$ \\
\hline
\end{tabular}

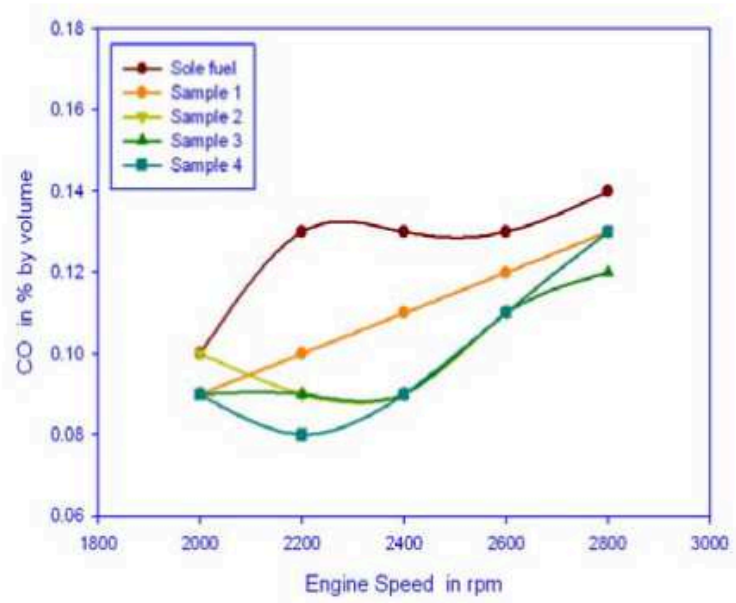

Figure 6 :Stage I and II CO vs engine speed [19]

\section{Conclusion}

In order to minimize the consumption of fossil fuel, bio additive start to be introduced as the alternative instead ofchemical based additive in purpose to reduce the emission and at the same time at least sustain the engine performance. These bioadditive can be extract from nature such sugar cane, corn, wheat and Malaysia start looking into palm oil as bio additive for diesel and petrol. Ethanol as the famous bio-fuels is widely used has the good antiknocking chracteristic, meanwhile the combination of ethanol with the bio additive could be considered to enhance the engine performance. Although the number of studies is small, it does appear this combination has the capability to enhance the engine performance and reduce the emission gases. Futher study on combination of bio-fuels with bio-additive is necessary to extend the knowledge in understanding the chemical reaction between these two substance.

\section{Acknowledgement}

The authors also would like to thank the Ministry of Higher Education Malaysia for supporting this research under the Fundamental Research Grant Scheme (FRGS) vot.1054.

\section{References}

[1] S. Er and S. A. E. N. Farm, "221 A Gasoline Additives- A Review”, 2014.

[2] Amir Khalid, N.Tamaldin, M. Jaat, M. F. M. Ali, B. Manshoor, Izzuddin Zaman, "Impacts of biodiesel storage duration on fuel properties and emissions", Procedia Engineering, volume 68, 2013, Pages 225 - 230, Elsevier, 2013, DOI: 10.1016/j.proeng.2013.12.172.

[3] Amir Khalid, M.D. Anuar, Yusri Ishak, B. Manshoor, Azwan Sapit, Mutalib Leman, Izzuddin Zaman, "Emissions characteristics of small diesel engine fuelled by waste cooking oil", MATEC Web of Conferences, Volume 13, 2014, Article number 06006, DOI: $10.1051 /$ matecconf/20141306006. 
[4] E. Sadeghinezhad, S. N. Kazi, F. Sadeghinejad, A. Badarudin, M. Mehrali, R. Sadri, and M. Reza Safaei, "A comprehensive literature review of bio-fuel performance in internal combustion engine and relevant costs involvement," Renewable and Sustainable Energy Reviews, vol. 30. pp. 29-44, 2014.

[5] Amir Khalid, Keisuke Hayashi, Yoshiyuki Kidoguchi , Tomoaki Yatsufusa, "Effect of air entrainment and oxygen concentration on endothermic and heat recovery process of diesel ignition", (2011) SAE Technical Papers, DOI: 10.4271/2011-01-1834.

[6] Amir Khalid, Norazwan Azman, Hanis Zakaria, B. Manshoor, Izzuddin Zaman, Azwan Sapit, Mutalib Leman, "Effects of storage duration on biodiesel properties derived from waste cooking oil", Applied Mechanics and Materials, Volume 554, 2014, Pages 494-499, DOI: $10.4028 / w w w . s c i e n t i f i c . n e t / A M M .554 .494$.

[7] E. R. Streva, L. Vinícius, M. Pereira, and J. R. Sodré, "Gasoline-Ethanol Blend Aging Effects on Engine Performance and Exhaust Emissions Reprinted From: Gasoline Direct Injection Engine and Spark Ignition Performance," no. 724, 2003.

[8] M. Al-Hasan, "Effect of ethanol-unleaded gasoline blends on engine performance and exhaust emission," Energy Convers. Manag., vol. 44, no. 9, pp. 1547-1561, Jun. 2003.

[9] M. Shahabuddin, H. H. Masjuki, M. a. Kalam, M. Mofijur, M. a. Hazrat, and a. M. Liaquat, "Effect of Additive on Performance of C.I. Engine Fuelled with Bio Diesel," Energy Procedia, vol. 14, no. 2011, pp. 1624-1629, Jan. 2012.

[10]C. Park, Y. Choi, C. Kim, S. Oh, G. Lim, and Y. Moriyoshi, "Performance and exhaust emission characteristics of a spark ignition engine using ethanol and ethanol-reformed gas," Fuel, vol. 89, no. 8, pp. 2118-2125, Aug. 2010.

[11]J. R. Tavares, M. S. Sthel, L. S. Campos, M. V. Rocha, G. R. Lima, M. G. da Silva, and H. Vargas, "Evaluation of Pollutant Gases Emitted by Ethanol and Gasoline Powered Vehicles," Procedia Environ. Sci., vol. 4, pp. 51-60, Jan. 2011.

[12] J. Y. Favez, M. Weilenmann, and J. Stilli, "Cold start extra emissions as a function of engine stop time: Evolution over the last 10 years," Atmos. Environ., vol. 43, pp. 996-1007, 2009.

[13]T. Topgül, H. S. Yücesu, C. Çinar, and A. Koca, "The effects of ethanol-unleaded gasoline blends and ignition timing on engine performance and exhaust emissions," Renew. Energy, vol. 31, no. 15, pp. 2534-2542, Dec. 2006.

[14] M. Koç, Y. Sekmen, T. Topgül, and H. S. Yücesu, "The effects of ethanol-unleaded gasoline blends on engine performance and exhaust emissions in a spark-ignition engine," Renew. Energy, vol. 34, no. 10, pp. 2101-2106, Oct. 2009.

[15] D. Turner, H. Xu, R. F. Cracknell, V. Natarajan, and X. Chen, "Combustion performance of bio-ethanol at various blend ratios in a gasoline direct injection engine," Fuel, vol. 90, no. 5, pp. 1999-2006, May 2011.

[16] H. Bayraktar, "Experimental and theoretical investigation of using gasoline-ethanol blends in spark-ignition engines," Renew. Energy, vol. 30, no. 11, pp. 1733-1747, Sep. 2005.

[17] C. Yao, Z. Zhang, Y. Xu, and Y. Huang, "Experimental investigation of effects of bio-additives on fuel economy of the gasoline engine," Sci. China Ser. E Technol. Sci., vol. 51, no. 8, pp. 1177-1185, Jul. 2008.

[18] G. Labeckas and S. Slavinskas, "Comparative performance of direct injection diesel engine operating on ethanol, petrol and rapeseed oil blends," Energy Convers. Manag., vol. 50, no. 3, pp. 792-801, 2009.

[19] C. A. Srinivasan and C. G. Saravanan, "Study of Combustion Characteristics of an SI Engine Fuelled with Ethanol and Oxygenated Fuel Additives," vol. 1, pp. 85-91, 2010. 